\title{
Performance of high-yielding dairy cows supplemented with fat or concentrate under hot and humid climates
}

\author{
U. Moallem,${ }^{* 1}$ G. Altmark, $\dagger$ H. Lehrer, ${ }^{*}$ and A. Arieli† \\ *Department of Dairy Cattle, Institute of Animal Sciences, Volcani Center, Bet-Dagan, 50250 Israel \\ †Department of Animal Science, The Robert H. Smith Faculty of Agriculture, Food and Environment Quality Sciences, \\ the Hebrew University of Jerusalem, Rehovot, 76-100 Israel
}

\section{ABSTRACT}

Multiparous Israeli-Holstein cows $(\mathrm{n}=42)$ averaging $158 \mathrm{~d}$ in milk and $621 \mathrm{~kg}$ of body weight were used to investigate the effects of energy source (fat or concentrate) on production, rumination time, energy balance, metabolic heat production, and efficiency under hot and humid conditions. Cows were assigned to 3 diet treatment groups: a lactating-cow ration $(1.75 \mathrm{Mcal}$ of net energy for lactation/kg of dry matter (DM; control); supplemented with $0.825 \mathrm{~kg} / \mathrm{d}$ per cow of ground corn grain (2.7\% of diet; HG); or supplemented with $0.300 \mathrm{~kg} / \mathrm{d}$ per cow of calcium salts of fatty acids $(1.5 \%$ of diet; HF). Milk production, body weight, and rumination time were recorded daily. Rectal temperature and respiratory rate $(\mathrm{RR})$ were measured weekly. Mean daily maximum ambient temperature, relative humidity, and temperature-humidity index were $31.5^{\circ} \mathrm{C}$, $86.6 \%$, and 76.8 , respectively. Dry matter intake was lower in $\mathrm{HF}$ and $\mathrm{HG}$ cows than in controls. Average daily rumination time was lowest in the HG group: 393.0, 377.7, and $390.8 \mathrm{~min} / \mathrm{d}$ for control, HG, and HF cows, respectively. Milk production was higher in the control group than in the HG group; milk fat content was 0.38 units higher and fat yield was $11 \%$ greater in HF cows than in HG cows. Fat-corrected milk yield was higher in HF cows than in HG cows, but not higher than in controls. Energy balance in HF cows was lower than in both other groups, and nonesterified fatty acid concentrations in plasma were increased by fat supplementation. Rectal temperature was highest in HF cows, and RR was higher in the HF cows than in the controls. Metabolic heat production was similar in HG and HF cows and lower than in controls. Body weight gain of the HG cows tended to be higher than that of the others. Efficiency of conversion of DM or energy intake to milk and fat-corrected milk was higher in HF cows than in both other groups; however, when taking the energy retention in body mass into account, no dif-

Received December 7, 2009.

Accepted March 13, 2010.

${ }^{1}$ Corresponding author: uzim@volcani.agri.gov.il ferences in energy utilization were observed between HF and HG groups. A principal component analysis revealed that rumination time played a pivotal role in the deleterious effect of heat stress in dairy cows. In conclusion, increasing the energy density in diets of heat-stressed mid-lactation cows over $1.75 \mathrm{Mcal} / \mathrm{kg}$ of DM was not effective in enhancing production. Both dietary treatments were effective in reducing metabolic heat production, but the changes were not reflected in rectal temperature and RR. Fat supplementation increased metabolic efficiency; however, whereas HF cows prioritized milk production, HG cows channeled energy for body mass deposition.

Key words: heat stress, fat supplementation, energy partitioning, rumination time

\section{INTRODUCTION}

Enhancing milk production during the hot season is of especial interest in Israel because of the increased demand for milk and milk products during the summer. However, the yields and performance of dairy cows under heat stress conditions are always reduced (West, 2003; Berman, 2008). The effects of hot and humid climate are thought to be mediated by body temperature, and it was reported that rectal temperature (RT) increased by $0.02^{\circ} \mathrm{C} / \mathrm{kg}$ of $\mathrm{FCM}$ for a cow producing $>25 \mathrm{~kg} / \mathrm{d}$ (Berman et al., 1985). Metabolic heat production (MHP) also increased as milk yields increased (Purwanto et al., 1990). Therefore, in light of the dramatic increase in milk production in the last 25 $y r$, it is plausible that adverse effects of heat stress on production have intensified in the modern high-yielding dairy cow. Increases in MHP often impair milk yield (West, 2003); therefore, using nutritional strategies to enhance milk production under heat-load conditions should take increased MHP into account.

Energy intake is considered the most production-limiting nutrition component during summer (West, 2003). However, recently it was demonstrated that reduced intake accounted for only $35 \%$ of the decline in milk yield under heat stress conditions, and it was suggested 
that a shift in postabsorptive metabolism and nutrient partitioning might account for the remaining reduction in milk yield (Rhoads et al., 2009). Alternations in plasma concentrations of several hormones were found in heat-stressed cows: observed changes in thyroxine, growth hormone, and glucocorticoids concentrations in chronically heat-stressed cattle were associated with reduced basal metabolism (Collier et al., 1982), and expression of gene networks was also shown to change in response to heat stress (Collier et al., 2008). However, direct effects of hormonal and gene expression changes on milk production in heat-load conditions were not demonstrated.

Increasing the energy intake of heat-stressed cows could be achieved via 2 main approaches: by increasing the concentrate content at the expense of dietary forage, or by fat supplementation. Fat supplementation is thought to be preferable because fat digestion, especially that of inert fat, in the rumen is minimal, so this practice might supply extra energy to the cow with less MHP (West, 2003). Several studies investigated the effects of fat supplementation during the hot season on production, and results have varied. Increasing dietary fat density from 4.6 to $7.4 \%$ in heat-stressed cows improved milk production efficiency by $9 \%$ in cows maintained in sheds, but not in those kept under an evaporative cooling regimen (Chan et al., 1997). Likewise, increasing dietary fat enhanced milk production in the warm season but not in the cool season (Skaar et al., 1989). In contrast, another study found greater milk production in thermoneutral cows than in heatstressed fat-supplemented cows (Knapp and Grummer, 1991). Increasing dietary fat from 2.6 to $6 \%$ in heatstressed mid-lactation cows enhanced milk production and efficiency and tended to increase energy retention (Drackley et al., 2003). The inconsistency in results could be attributed to variations in heat stress intensity or to other factors, such as energy density and housing conditions.

Cows under thermoneutral conditions fed a diet high in glucogenic nutrients have been shown to channel nutrients toward body reserves, whereas cows fed a lipogenic diet produced more milk containing more fat and energy (van Knegsel et al., 2007). There is a lack of knowledge on the effect of the type of nutrient supplementation on energy-partitioning priorities of the heat-stressed cow. The only study that compared the effect of lipogenic versus glucogenic substrates on the metabolism of heat-stressed cows was conducted by Drackley et al. (2003); however, the diets in that trial contained only a moderate $\mathrm{NE}_{\mathrm{L}}$ content (1.5 to 1.6 $\mathrm{Mcal} / \mathrm{kg}$ of DM).

Heat stress in ruminants was associated with reductions in both frequency and amplitude of rumen con- tractions (Attebery and Johnson. 1969) and an increase of digestion of DM and fiber components (Beede and Collier, 1986). Beede and Collier (1986) reviewed several other factors, such as water intake and appetite, that might affect digestibility under heat stress. In the present study we measured rumination time, hypothesizing that it might be influenced directly by heat stress with respect to dietary manipulations.

We hypothesized that increasing the energy density beyond $1.75 \mathrm{Mcal} / \mathrm{kg}$ of DM would increase milk production and that protected fat supplementation might decrease MHP and therefore be more efficient than concentrate in increasing production. The objectives were to examine the effects of energy supplementation, either as fat or as concentrates, of high-yielding dairy cows that already were maintained on high-energy diets on production, energy partitioning, energy balance, rumination time, and efficiency of milk production during hot and humid conditions.

\section{MATERIALS AND METHODS}

\section{Cows and Treatments}

The procedures used were approved by the Volcani Center Animal Care Committee. The experiment was conducted at the Volcani Center experimental farm in Bet Dagan, Israel, and continued from early July to mid September (11 wk), which typically is the hot season in Israel. Forty-two multiparous Israeli-Holstein dairy cows averaging 158 DIM $(\mathrm{SD}=36)$ and 621 $\mathrm{kg}$ of $\mathrm{BW}(\mathrm{SD}=52)$ were housed in covered loose pens with adjacent outside yards that were equipped with a real-time electronic individual feeding system. Each feeding station was equipped with an individual identification system (I.D. tag, SAE Kibutz Afikim, Israel) that allowed each cow to enter a specific feeding station and automatically recorded each meal. After $10 \mathrm{~d}$ of adaptation to the feeding stations, cows were divided into 3 treatment groups, each with 14 cows. Cows were stratified randomly within stratum and strata were defined by milk production, DIM, parity, and BW. Dietary treatments were as follows: lactating cow ration formulated to meet NRC (2001) nutrient requirements (1.75 Mcal of $\mathrm{NE}_{\mathrm{L}} / \mathrm{kg}$ of $\mathrm{DM}$; control); control diet supplemented with $0.825 \mathrm{~kg} / \mathrm{d}$ per cow of ground corn (2.7\% of diet, DM basis; HG); or control diet supplemented with $0.300 \mathrm{~kg} / \mathrm{d}$ per cow $(1.5 \%$ of diet, DM basis) of calcium salts of fatty acids of palm oil distillate (Adolac, Koffolk, Tel Aviv, Israel; HF). The average milk production, DIM, and BW at the beginning of the experiment for control, HG, and HF cows were, respectively, $45.6,45.7$, and $45.0 \mathrm{~kg} / \mathrm{d}$ (SD $=4.6), 155.7,158.5$, and $161.2 \mathrm{~d}(\mathrm{SD}=36)$, and 618.0, 
Table 1. Ingredients and chemical composition of the experimental $\operatorname{diets}^{1}$

\begin{tabular}{lcrc}
\hline Item & Control & HG & HF \\
\hline Ingredient, \% of DM & & & \\
Corn grain, ground & 25.0 & 27.4 & 24.7 \\
Barley grain, rolled & 3.5 & 3.4 & 3.4 \\
Soybean meal & 6.7 & 6.5 & 6.6 \\
Sunflower meal & 1.3 & 1.3 & 1.3 \\
Wheat bran & 7.8 & 7.6 & 7.7 \\
Corn gluten feed & 8.7 & 8.4 & 8.5 \\
Cottonseed & 3.5 & 3.4 & 3.5 \\
Wheat silage & 17.0 & 16.5 & 16.8 \\
Corn silage & 5.1 & 4.9 & 5.0 \\
Dried distillers grain & 7.7 & 7.5 & 7.6 \\
Soybean + molasses & 1.1 & 1.1 & 1.1 \\
Oats hay & 8.3 & 8.0 & 8.2 \\
Calcium salts of fatty acids & 1.1 & 1.0 & 2.5 \\
Salt & 1.4 & 1.4 & 1.4 \\
Urea & 0.3 & 0.3 & 0.3 \\
Calcium bicarbonate & 0.7 & 0.7 & 0.7 \\
Limestone & 0.6 & 0.6 & 0.6 \\
Vitamins and minerals ${ }^{2}$ & 0.1 & 0.1 & 0.1 \\
Chemical composition & & & \\
NE ${ }^{2}$ Mcal/kg & 1.75 & 1.78 & 1.79 \\
CP, \% & 17.0 & 16.8 & 16.8 \\
NDF, \% & 32.8 & 32.1 & 32.4 \\
Forage NDF, \% & 17.0 & 16.5 & 16.8 \\
Ether extract, \% & 5.1 & 5.1 & 6.6 \\
Ca, \% & 0.9 & 0.9 & 0.9 \\
P, \% & 0.4 & 0.4 & 0.4 \\
\hline Conti & & & \\
\hline
\end{tabular}

${ }^{1}$ Control: a lactating cow ration $\left(1.75 \mathrm{Mcal}\right.$ of $\mathrm{NE}_{\mathrm{L}} / \mathrm{kg}$ of DM); HG: supplemented with $0.825 \mathrm{~kg} / \mathrm{d}$ per cow of ground corn grain $(2.7 \%$ of diet); HF: supplemented with $0.300 \mathrm{~kg} / \mathrm{d}$ per cow of calcium salts of fatty acids ( $1.5 \%$ of diet).

${ }^{2}$ Contained 20,000,000 IU $/ \mathrm{kg}$ of vitamin A, 2,000,000 IU $/ \mathrm{kg}$ of vitamin $\mathrm{D}, 15,000 \mathrm{IU} / \mathrm{kg}$ of vitamin E, 6,000 $\mathrm{mg} / \mathrm{kg}$ of $\mathrm{Mn}, 6,000 \mathrm{mg} / \mathrm{kg}$ of $\mathrm{Zn}$, $2,000 \mathrm{mg} / \mathrm{kg}$ of Fe, $1,500 \mathrm{mg} / \mathrm{kg}$ of $\mathrm{Cu}, 120 \mathrm{mg} / \mathrm{kg}$ of I, $50 \mathrm{mg} / \mathrm{kg}$ of Se, and $20 \mathrm{mg} / \mathrm{kg}$ of $\mathrm{Co}$.

${ }^{3}$ Calculated using NRC (2001) values.

622.7 , and $626.7 \mathrm{~kg}(\mathrm{SD}=52)$. The composition and chemical contents of the diets are presented in Table 1. The fat supplement consisted of $15 \%$ ash and $84 \%$ fatty acids (DM basis). Fatty acid composition of the fat supplement was 1\% C14:0, 45.0\% C16:0, 5\% C18:0, $40 \%$ C18:1, and 9\% C18:2. Diets were individually fed as a TMR once daily at $1100 \mathrm{~h}$, and the supplements were individually hand-mixed into the upper half of the TMR. Amounts of feed offered were adjusted daily to allow $7 \%$ orts, and feed offered and orts were recorded daily for individual intake calculations.

During the study period cows were cooled 5 times/d in the holding pen of the milking parlor. Each cooling period lasted $30 \mathrm{~min}$, comprising cycles of $30 \mathrm{~s}$ of showering and $4.5 \mathrm{~min}$ of ventilation without showering.

\section{Measurements}

Ambient temperature (AT) and relative humidity (RH) measurements were recorded every $3 \mathrm{~h}$ by the
Israel Meteorological Service (Bet Dagan, Israel). Maximum RH and minimum AT were determined at 0300 $\mathrm{h}$, and minimum RH and maximum AT were determined at $1200 \mathrm{~h}$. Accordingly, minimum and maximum temperature-humidity index (THI) were determined at 0300 and $1200 \mathrm{~h}$, respectively. The following equation was used for THI calculation (Bohmanova et al., 2007):

$$
\begin{aligned}
\mathrm{THI}=(1.8 \times & \left.\mathrm{T}_{\mathrm{db}}+32\right)-(0.55-0.0055 \times \mathrm{RH}) \\
& \times\left(1.8 \times \mathrm{T}_{\mathrm{db}}-26\right),
\end{aligned}
$$

where $T_{d b}$ is dry bulb temperature.

Cows were milked 3 times daily and milk production was recorded electronically. Cows were weighed automatically after each milking with a walking electronic scale. Milk samples were collected from 3 consecutive milkings every $2 \mathrm{wk}$, and milk fat, protein, and lactose were determined by infrared analysis (standard IDF 141C; IDF, 2000) at the laboratories of the Israeli Cattle Breeders' Association (Caesarea, Israel). Energy content in milk was calculated according to NRC (2001) equations.

Energy balance (EB) was calculated daily according to NRC (2001) as follows:

$$
\begin{gathered}
\mathrm{NE}_{\mathrm{C}}=\mathrm{NE}_{\mathrm{L}} \text { per } \mathrm{kg} \text { of } \mathrm{DM} \times \mathrm{DMI} ; \\
\mathrm{NE}_{\mathrm{M}}=\mathrm{BW}^{0.75} \times 0.08 \times 1.1 ;
\end{gathered}
$$

$$
\begin{gathered}
\mathrm{NE}_{\mathrm{P}}=\text { milk }(\mathrm{kg}) \times\{[0.0929 \times(\text { fat \% })]+[0.0547 \\
\times(\text { protein \% })]+[0.0395 \times(\text { lactose \% })]\} ; \text { and } \\
\mathrm{EB}=\mathrm{NE}_{\mathrm{C}}-\left(\mathrm{NE}_{\mathrm{M}}+\mathrm{NE}_{\mathrm{P}}\right)
\end{gathered}
$$

where $\mathrm{NE}_{\mathrm{C}}=$ net energy consumed and $\mathrm{NE}_{\mathrm{P}}=$ net energy output in milk.

The ME intake (MEI) was calculated by using the NRC (2001) equations, with modifications to adjust for metabolic efficiency of diets containing more than $3 \%$ of ether extracts as in the present study (NRC, 2001).

Conversion of feed DM to milk and FCM was calculated from the daily individual data. The individual mean values of energy intake, energy output in milk, and BW gain for the entire study period were used for energy efficiency calculations. The $\mathrm{NE}_{\mathrm{L}}$ provided by BW loss or gain $\left(\mathrm{NE}_{\mathrm{R}}\right)$ was determined by using $\mathrm{NRC}$ (2001) values.

Indirect MHP was calculated as

$$
\mathrm{MHP}=\mathrm{MEI}-\left(\mathrm{NE}_{\mathrm{P}}+\mathrm{NE}_{\mathrm{R}}+\mathrm{NE}_{\mathrm{M}}\right),
$$


where $\mathrm{NE}_{\mathrm{R}}$ is $\mathrm{NE}_{\mathrm{L}}$ provided by $\mathrm{BW}$ loss or gain.

The cows were equipped with collar-mounted tags (HR-Tags, SCR Engineers Ltd., Hadarim Netanya, Israel) that monitored and transmitted rumination time. Rumination data were recorded by a special microphone that detected chewing actions by analyzing vocal signals. Data were stored in 2-h blocks and recorded 3 times daily at the milking parlor throughout the entire study period.

Respiratory rate (RR) and RT were recorded weekly after the noon milking at $1400 \mathrm{~h}$, on average $1 \mathrm{~h}$ after a cooling session. Rectal temperature was recorded by a clinical thermometer inserted into the rectum. Respiration rates were measured by counting flank movements during $1 \mathrm{~min}$, as recorded with a stopwatch.

Blood samples were taken twice during the experiment, 30 and $60 \mathrm{~d}$ after commencement of the dietary treatments, after the morning milking at $0800 \mathrm{~h}$. They were collected by coccygeal venipuncture, taken into vacuum tubes (Becton Dickinson Systems, Cowley, England), and immediately placed on ice. Plasma was separated from the samples and stored at $-18^{\circ} \mathrm{C}$ pending analysis.

\section{Chemical Analysis}

Total mixed rations were sampled weekly, and DM, $\mathrm{CP}, \mathrm{NDF}, \mathrm{ADF}, \mathrm{Ca}$, and $\mathrm{P}$ were determined. Feed samples were dried at $65^{\circ} \mathrm{C}$ for $24 \mathrm{~h}$ and ground to pass through a 1.0-mm screen (Retsch S-M-100, Retsch GmbH, Haan, Germany). The ground samples were dried at $100^{\circ} \mathrm{C}$ for $24 \mathrm{~h}$ and analyzed for $\mathrm{N}$ (AOAC, 1990; method 984.13), Ca (AOAC, 1990; method 935.13), and P (AOAC, 1990; method and 964.06). Neutral detergent fiber and ADF contents were determined with Ankom equipment (Ankom Technology, Fairport, NY; NDF using $\alpha$-amylase and sodium sulfite). The $\mathrm{NE}_{\mathrm{L}}$ values for feedstuffs in the formulated diets were calculated according to the values of NRC (2001).

The NEFA concentrations in plasma were determined with a NEFA C Test Kit (Wako Chemicals GmbH, Neuss, Germany). Glucose concentrations in plasma were determined with a Glucose Hexokinase Reagent Set (Pointe Scientific Inc., Canton, MI). The intra- and interassay coefficients of variation for NEFA assay were 6.9 and $6.1 \%$, respectively, and those for glucose assay were 2.6 and $2.2 \%$, respectively.

\section{Statistical Analysis}

Continuous variables such as DMI, milk and milk solids, rumination time, and metabolites were analyzed as repeated measurements using the PROC MIXED procedure of SAS software (version 9.2; SAS Institute,
2002). Each relevant variable was analyzed with the specific data of the pretreatment period as covariable.

The model used was

$$
\begin{aligned}
Y_{\mathrm{ijklmn}}=\mu & \mathrm{T}_{\mathrm{i}}+\mathrm{L}_{\mathrm{j}}+\mathrm{C}(\mathrm{T} \times \mathrm{L})_{\mathrm{ijk}}+\mathrm{DOT}_{\mathrm{ijkl}} \\
& +\mathrm{DIM}_{\mathrm{ijklm}}+\mathrm{E}_{\mathrm{ijk} \mathrm{kmn}},
\end{aligned}
$$

where $Y_{\mathrm{ijklmn}}=$ dependent variable; $\mu=$ overall mean; $\mathrm{T}_{\mathrm{i}}=$ treatment effect, $\mathrm{i}=1$ to $3 ; \mathrm{L}_{\mathrm{j}}=$ parity, $\mathrm{j}=2$ or $>2 ; \mathrm{C}(\mathrm{T} \times \mathrm{L})_{\mathrm{ijk}}=$ cow k nested in treatment $\mathrm{i}$ and parity $\mathrm{j} ; \mathrm{DOT}_{\mathrm{ijkl}}=$ days on treatment; $\mathrm{DIM}_{\mathrm{ijklm}}=$ day in milk as continuous variable; and $\mathrm{E}_{\mathrm{ijk} k \mathrm{mn}}=$ random residual.

The autoregressive order 1 was used as a covariance structure in the model. Treatment $\times$ time interactions were tested and found not significant for any variables that were analyzed; therefore, they were excluded from the model. Body weight gain was analyzed using the GLM procedure of SAS (version 9.2; SAS Institute, 2002). Regression analysis was performed with the REG procedure of SAS (version 9.2; SAS Institute, 2002). Cross-treatment relationships between milk production, DMI, THI, DIM, and rumination time were analyzed with the principal component analysis of SAS (version 9.2; SAS Institute, 2002).

Comparisons for all variables were control versus HG $+\mathrm{HF}$ (high energy effect), HF versus control + HG (HF effect), and HG versus HF (source of energy effect). Least squares means and adjusted standard error of the means are presented in Tables 2,3 , and 4 . The value $P<0.05$ was accepted as significant and tendencies were reported at $0.05<P<0.10$.

\section{RESULTS AND DISCUSSION}

Mean daily maximum and minimum AT were $31.5^{\circ} \mathrm{C}$ $(\mathrm{SD}=0.7)$ and $22.9^{\circ} \mathrm{C}(\mathrm{SD}=1.6)$, respectively, and daily mean maximum and minimum $\mathrm{RH}$ were $86.6 \%$ $(\mathrm{SD}=4.9)$ and $50.4 \%(\mathrm{SD}=5.9)$, respectively. Except for 2 nights, the minimum temperature did not decrease below $21^{\circ} \mathrm{C}$, which prevented cooling of cows during the evening hours and in consequence caused accumulative heat load (Igono et al., 1992). Daily mean THI during the study was $76.8(\mathrm{SD}=1.6$; Figure $1 \mathrm{~A})$, which was 4.8 units above the value of 72 that was determined by Igono et al. (1992) as being critical for milk production. Heat stress during the study period was typical of the summer season in the coastal plain of Israel, which is characterized by stable hot and humid weather with minor fluctuations.

Average DMI of all groups $(23.1 \mathrm{~kg} / \mathrm{d})$ was $9.1 \%$ lower than that predicted by the NRC (2001) model (i.e., $25.4 \mathrm{~kg} / \mathrm{d}$ for cows having similar DIM, BW, and 
MOALLEM ET AL.

Table 2. Least squares means of DMI, energy intake, milk and milk solids yields, and energy output in milk

\begin{tabular}{|c|c|c|c|c|c|c|c|}
\hline \multirow[b]{2}{*}{ Item } & \multicolumn{3}{|c|}{ Treatment $^{1}$} & \multirow[b]{2}{*}{ SEM } & \multicolumn{3}{|c|}{$P$-value for contrasts } \\
\hline & Control & $\mathrm{HG}$ & $\mathrm{HF}$ & & $\begin{array}{l}\text { Control vs. } \\
\mathrm{HG}+\mathrm{HF}\end{array}$ & $\begin{array}{c}\text { HF vs. } \\
\text { control }+\mathrm{HG}\end{array}$ & $\begin{array}{c}\text { HF vs. } \\
\text { HG }\end{array}$ \\
\hline DMI, $\mathrm{kg} / \mathrm{d}$ & 23.6 & 22.8 & 22.9 & 0.09 & 0.001 & 0.007 & 0.7 \\
\hline $\mathrm{NE}_{\mathrm{L}}$ intake, Mcal/d & 41.3 & 40.6 & 40.9 & 0.27 & 0.02 & 0.77 & 0.24 \\
\hline $\mathrm{ME}$ intake, Mcal/d & 64.8 & 63.6 & 63.8 & 0.28 & 0.003 & 0.23 & 0.62 \\
\hline \multicolumn{8}{|l|}{ Milk yield } \\
\hline Milk, kg/d & 40.8 & 40.0 & 40.3 & 0.27 & 0.06 & 0.76 & 0.40 \\
\hline Milk energy output, Mcal/d & 26.7 & 25.8 & 27.2 & 0.24 & 0.04 & 0.007 & 0.001 \\
\hline $4 \% \mathrm{FCM}, \mathrm{kg} / \mathrm{d}$ & 36.2 & 34.6 & 36.5 & 0.32 & 0.08 & 0.02 & 0.002 \\
\hline \multicolumn{8}{|l|}{ Milk solids contents and yields } \\
\hline Fat, $\%$ & 3.31 & 3.18 & 3.56 & 0.97 & 0.67 & 0.01 & 0.04 \\
\hline Protein, \% & 3.01 & 3.10 & 3.10 & 0.04 & 0.007 & 0.18 & 0.98 \\
\hline Lactose, \% & 4.79 & 4.81 & 4.76 & 0.03 & 0.96 & 0.20 & 0.28 \\
\hline $\mathrm{TS}, \%$ & 11.1 & 11.1 & 11.4 & 0.09 & 0.32 & 0.02 & 0.08 \\
\hline Fat, kg/d & 1.28 & 1.20 & 1.33 & 0.04 & 0.66 & 0.10 & 0.07 \\
\hline Protein, kg/d & 1.18 & 1.18 & 1.17 & 0.02 & 0.94 & 0.64 & 0.68 \\
\hline Lactose, $\mathrm{kg} / \mathrm{d}$ & 1.87 & 1.84 & 1.80 & 0.04 & 0.40 & 0.32 & 0.68 \\
\hline
\end{tabular}

${ }^{1}$ Control: a lactating cow ration (1.75 Mcal of $\mathrm{NE}_{\mathrm{L}} / \mathrm{kg}$ of DM); HG: supplemented with $0.825 \mathrm{~kg} / \mathrm{d}$ per cow of ground corn grain $(2.7 \%$ of diet); HF: supplemented with $0.300 \mathrm{~kg} / \mathrm{d}$ per cow of calcium salts of fatty acids (1.5\% of diet).

production). Average DMI was 3.4 and $3 \%$ lower in the HG and HF cows, respectively, than in the control $(P$ $<0.001$; Table 2; Figure 1C). As also shown in Table 2, DMI was reduced by higher energy density $(P<0.007)$ in contrast to findings of studies conducted under thermoneutral conditions (Vazquez-Añon et al., 1997) or with heat-stressed mid-lactation cows (Drackley et al., 2003). However, in both of these studies the energy density did not exceed $1.7 \mathrm{Mcal} / \mathrm{kg}$ of DM, compared with values $\geq 1.78 \mathrm{Mcal} / \mathrm{kg}$ of DM supplied to the treatment groups in the present study. Grum et al. (1996) suggested that increasing the dietary energy content to $1.7 \mathrm{Mcal} / \mathrm{kg}$ of DM increased the DMI, but that increasing it beyond that level might cause a decline in DMI. It appears that increasing the dietary energy density up to or beyond $1.78 \mathrm{Mcal} / \mathrm{kg}$ of DM during the hot season, as in the present study, resulted in reduced intake because of the combined effect of high-density diet and heat load, an effect that also was manifested in higher RT and RR.

Dry matter intake of the HF cows decreased from initiation of the study until the third week, probably because of adjustment to the experimental diet (Figure 1C). Although fat supplementation is generally

Table 3. Daily BW gain, energy balance, and the efficiency of conversion of consumed DM and energy for production (milk and BW deposition)

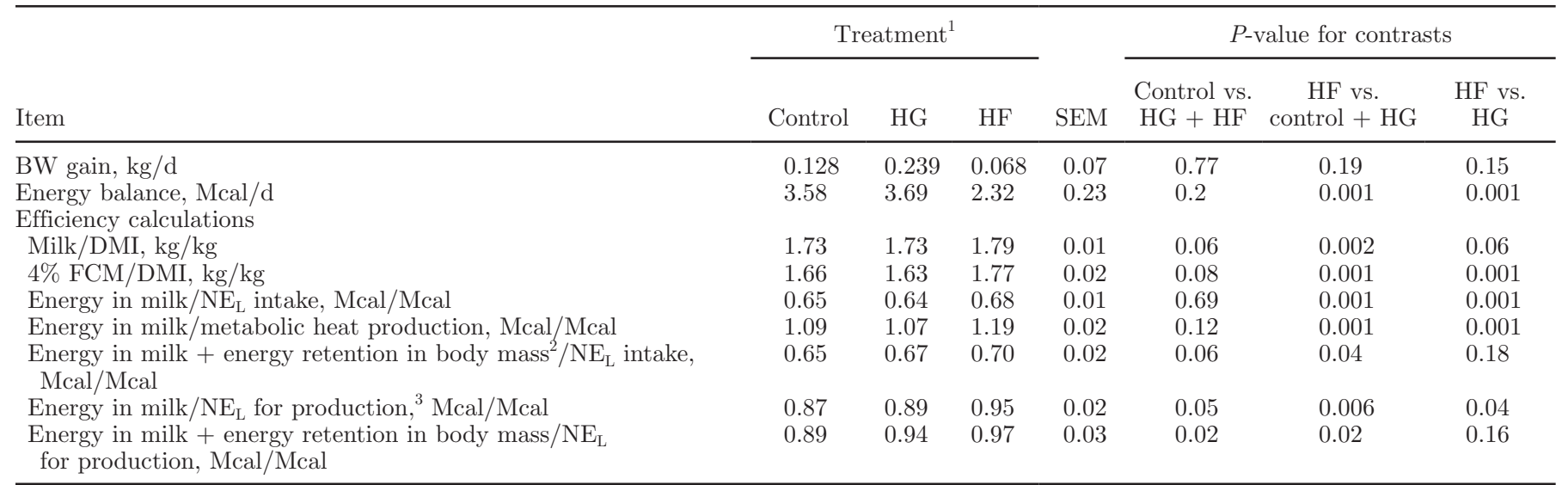

${ }^{1}$ Control: a lactating cow ration $\left(1.75 \mathrm{Mcal}\right.$ of $\mathrm{NE}_{\mathrm{L}} / \mathrm{kg}$ of $\left.\mathrm{DM}\right)$; HG: supplemented with $0.825 \mathrm{~kg} / \mathrm{d}$ per cow of ground corn grain $(2.7 \%$ of diet); HF: supplemented with $0.300 \mathrm{~kg} / \mathrm{d}$ per cow of calcium salts of fatty acids (1.5\% of diet).

${ }^{2}$ Energy deposited in BW mass.

${ }^{3} \mathrm{NE}_{\mathrm{L}}$ for production $=\mathrm{NE}_{\mathrm{L}}$ intake - energy required for maintenance. 
Table 4. Rumination time, rectal temperature, respiratory rate, metabolic heat production, and metabolites concentrations in plasma

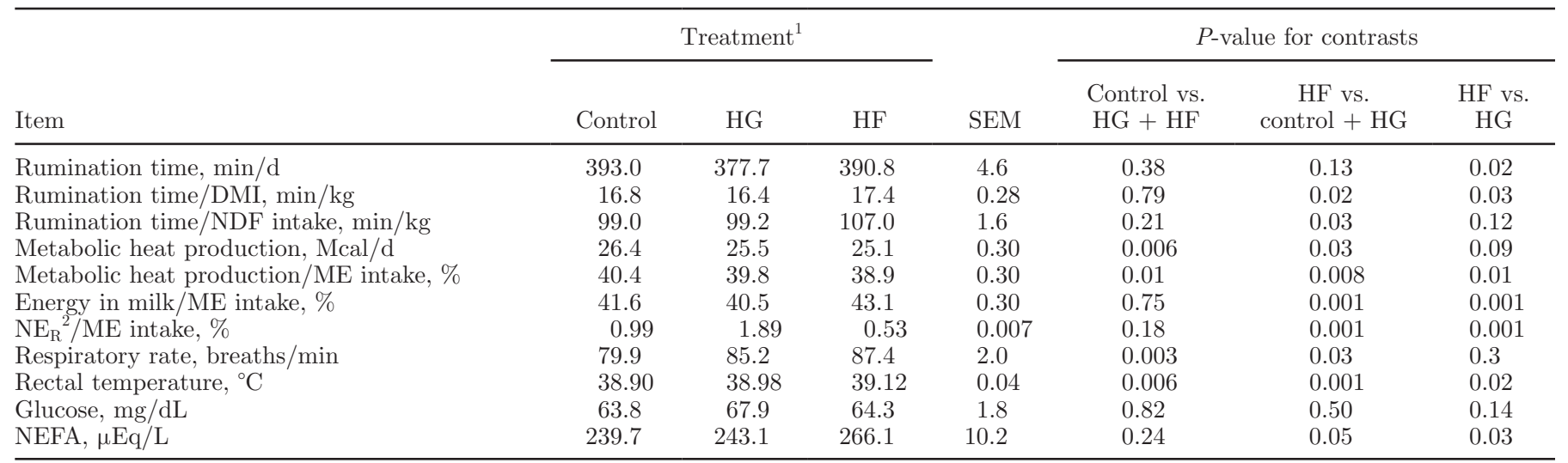

${ }^{1}$ Control: a lactating cow ration $\left(1.75 \mathrm{Mcal}\right.$ of $\mathrm{NE}_{\mathrm{L}} / \mathrm{kg}$ of DM); HG: supplemented with $0.825 \mathrm{~kg} / \mathrm{d}$ per cow of ground corn grain (2.7\% of diet); HF: supplemented with $0.300 \mathrm{~kg} / \mathrm{d}$ per cow of calcium salts of fatty acids (1.5\% of diet).

${ }^{2}$ Energy provided by BW loss or gain.

considered to depress intake, no reduction in DMI was reported when fat was supplemented in diets of mid- to late-lactation cows under thermoneutral conditions in various studies (Wu et al., 1993; Khorasani and Kennelly, 1998; Mosley et al., 2007). It was also concluded by Chilliard (1993), in a review of the subject, that the adverse effect of fat supplementation on DMI was considerably less during long-term mid-lactation studies than in short-term or early stage-lactation studies. However, supplementation of fat to mid-lactation cows during the summer season was reported to reduce DMI (Drackley et al., 2003) but not HG (i.e., HF was reported as decreasing DMI, whereas HG was not reported as decreasing DMI), which is partly consistent with the present findings; discrepancies might be related to dietary energy-density differences.

In the present study, FCM production of the control and $\mathrm{HF}$ cows was higher than that of the HG cows (4.6 and 5.5\%, respectively; $P<0.001$ ), with no differences between control and HF groups (Table 2; Figure 2A). Findings of other studies regarding effects of fat supplementation on FCM yields of mid-lactation cows have varied: in some studies under thermoneutral conditions no effects were observed (Grum et al., 1996; Vazquez-Añon et al., 1997; Khorasani and Kennelly, 1998), whereas Drackley et al. (2003) noted enhanced FCM yields in heat-stressed cows. Moreover, in the present study FCM yield tended $(P<0.08)$ to be lower for cows fed high-energy diets in contrast with reports of no observed effect of energy density on FCM yield (Vazquez-Añon et al., 1997; Drackley et al., 2003). These discrepancies between studies could be related to differences in energy density between diets, but also to differing production levels.

In the present study the milk fat content in the HF group was $0.38 \%$ higher than that in the $\mathrm{HG}$ group
$(P<0.01)$ and tended $(P<0.08)$ to be higher than in the control group, whereas the fat yield $(\mathrm{kg} / \mathrm{d})$ was $11 \%$ higher in the HF group than in the HG group $(P$ $<0.04$ ). The lower FCM yield of the HG cows could be related to the lower intake compared with that of the control group; however, the HF cows channeled extra nutrients toward fat yield, which resulted in higher FCM and energy output in milk than those in the HG group.

Body weight gain during the study period (Table 3 ; Figure 2B) showed no effects of fat or high-energy supplementation, but that of the HG cows was 2 and 3.5 times as great as those of the control and the HF cows, respectively $(P<0.09)$. It appears that, despite the lower intake of the HF cows, they channeled more energy to produce FCM and energy in milk (43.1 vs. $40.6 \%$ of MEI for HF and HG cows, respectively; $P<$ 0.0001; Table 4) at the expense of $\mathrm{BW}$ gain. On the other hand, the HG cows channeled more energy for body mass retention ( 0.53 vs. $1.88 \%$ of MEI for HF and HG cows, respectively; $P<0.0001$; Table 4) and produced less FCM and energy in milk. These findings indicate different partitioning of energy between fatand concentrate-supplemented cows, which resembles the findings of van Knegsel et al. (2007). The effect of HG in reducing fat content and yield was evident in the present study $(P<0.05)$, which is consistent with the suggestion of van Soest (1963) that milk fat-depressing diets increase the priority of BW gain at the expense of milk production.

Measurements of all parameters related to efficiency of conversion of consumed DM or energy to milk, FCM, or energy in milk showed that HF cow performance was higher compared with both other groups (Table 3). Efficiency of DMI utilization for milk production in HF cows was $3.5 \%$ higher than in both other groups, and 
conversion of DMI to FCM was 6.6 and $4.5 \%$ higher in the HF group than in the HG and control groups, respectively $(P<0.001)$. However, when taking the energy deposition in body mass into account, no differences between HF and HG groups were observed (Table $3)$. The higher efficiency of the HF cows related only to milk and milk solids production, but not to total energy use; HG cows used energy to enhance body mass deposition at the expense of milk production without reducing the overall energy utilization. This finding agrees with the suggestion of Chan et al. (1997) that increasing diet energy density by supplementation with nonfermentative nutrients might improve efficiency of conversion of feed to milk in heat-stressed cows.

Table 4 presents results of indirect MHP calculations. The MHP in HF cows accounted for $38.9 \%$ of MEI and was lower than in both other groups. Moreover, milk energy output in the HF group accounted for $43.1 \%$ of the MEI, which was $3.6 \%(P<0.007)$ and $6.4 \%(P<0.001)$ higher than that of the control and HG groups, respectively. Both the HG and HF diets reduced metabolic heat production by $4.2 \%$ compared with the control $(P<0.006)$, but MHP did not differ between the HG and HF diets, which does not support our hypothesis that the HF diet would be more effective than the HG diet in reducing MHP. It appears that MHP in the HG cows was reduced primarily by decreasing energy output in milk, differently from the HF group in which production remained high. Rectal temperature was higher in the HF cows than in the control $(P<0.001)$ and HG cows $(P<0.04$; Table 4$)$, and RR was higher in the HF cows than in the control cows $(P<0.01)$ and tended $(P<0.08)$ to be higher in the HG cows than in the controls. The lower MHP in the HG and HF groups than in the controls might have been expected to reduce RT and RR, but the low frequency and the pattern of these measurements in the present study may be insufficient to determine accurately the effects of dietary treatments. Furthermore, previous studies (Moody et al., 1967; Huber et al., 1994; Drackley et al., 2003) did not find differences in RT or RR between fat-supplemented and control cows. In light of these findings, it might be concluded that the direct effect of dietary manipulations on RT and RR is limited compared with climatic conditions effects.

Glucose and NEFA concentrations in plasma are shown in Table 4. Glucose concentrations in the HG groups tended $(P<0.08)$ to be higher than in both other groups (67.9 and $64.1 \mathrm{mg} / \mathrm{dL}$, respectively). The effect of HF supplementation on increasing NEFA concentrations in plasma was significant $(P<0.05$; Table 4). Higher NEFA concentrations in fat-supplemented peripartum cows were also reported (Grummer and Carroll., 1991; Sklan et al., 1991; Moallem et al., 2007)


Figure 1. Temporal changes during the study in A) weekly temperature-humidity index (THI), B) rumination time, and C) DMI of dairy cows fed a lactating cow ration $\left(1.75 \mathrm{Mcal}\right.$ of $\mathrm{NE}_{\mathrm{L}} / \mathrm{kg}$ of DM; control diet; $\bigcirc$ ) or supplemented with either $0.825 \mathrm{~kg} / \mathrm{d}$ per cow of ground corn grain $(\mathrm{HG}$ - $)$ or $0.300 \mathrm{~kg} / \mathrm{d}$ per cow of calcium salts of fatty acids $(\mathrm{HF} ; \mathbf{\Delta})$ during the hot season. Effects of treatment and time were significant for rumination time $(P<0.05$ and $P<0.02$, respectively $)$ and DMI $(P<0.001$ and $P<0.001$, respectively). Overall SEM was $14.4 \mathrm{~min} / \mathrm{d}$ and $0.44 \mathrm{~kg} / \mathrm{d}$ for rumination time and DMI, respectively.

in mid- to late-lactation cows (Vazquez-Añon et al., 1997; Drackley et al., 2003) under a variety of climatic conditions. Higher NEFA concentrations in fat-supplemented peripartum cows were mainly related to greater mobilization of adipose tissue, which was also reflected in greater BW loss. However, during mid to late lactation, dairy cows mostly have positive $\mathrm{EB}$, as also was 
observed in the present study, even for the HF cows. It is likely that the increase in NEFA concentration in cows supplemented with fat during mid to late lactation was caused by increased net release of fatty acids and reduced NEFA clearance by adipose tissues, as was suggested by Grummer and Carroll (1991).

The EB calculations in the present study revealed that cows in all groups were in positive EB. Rhoads et al. (2009) found that cows under severe heat stress housed in environmental chambers still had positive $\mathrm{EB}$, though the heat-stressed cows markedly lost BW. Similar heat-stress conditions to those in the present study caused negative EB in dairy cows housed in climatic chambers (Shwartz et al., 2009), but Drackley et al. (2003) observed BW gain in heat-stressed midlactation cows, which is consistent with our present findings. Rhoads et al. (2009) hypothesized that heat stress regulated EB by reducing milk energy production beyond the reduction in energy intake. Although the mechanism is unknown, this effect might be related to the inability of the adipose store to mobilize free fatty acids in heat-stressed cows. The inconsistencies among findings on the effect of heat stress on EB might be attributable to differences in milk yield and other experimental circumstances, but also to heat load levels, as reflected in differences between studies in RT measurements.

The present study also found that EB of the HF cows was lower than that of both other groups $(P<0.001$; Table 3). Several studies in early postpartum cows found that fat supplementation triggered enhanced production of milk or milk solids, although it worsened the EB of cows (Sklan et al., 1991; Chilliard, 1993). In a similar manner, in the present study HF cows under heat stress preferentially channeled energy to milk production and maintained high production levels, although the high level of production impaired their EB. The mechanism by which fat supplementation stimulated dairy cows to enhance production even under stress conditions and at the expense of their physiological status is still not clear.

Rumination time in all groups was within the range of 380 to $390 \mathrm{~min} / \mathrm{d}$ (Table 4; Figure 1B). According to Beauchemin et al. (1994), high-yielding dairy cows consuming large quantities of DM tended to ruminate for more than $360 \mathrm{~min} / \mathrm{d}$ in the absence of digestive disorder, and Kadzere et al. (2002) suggested that under severe heat stress intensive panting causes loss of a buffer with a consequent reduction in rumen $\mathrm{pH}$. Sharp reduction in rumen $\mathrm{pH}$ could increase dissociation between the calcium and the fatty molecules and, in turn, loss of ruminal fat protection (Sukhija and Palmquist, 1990). Though rumen $\mathrm{pH}$ was not measured in the present study, maintenance of the normal rumination time
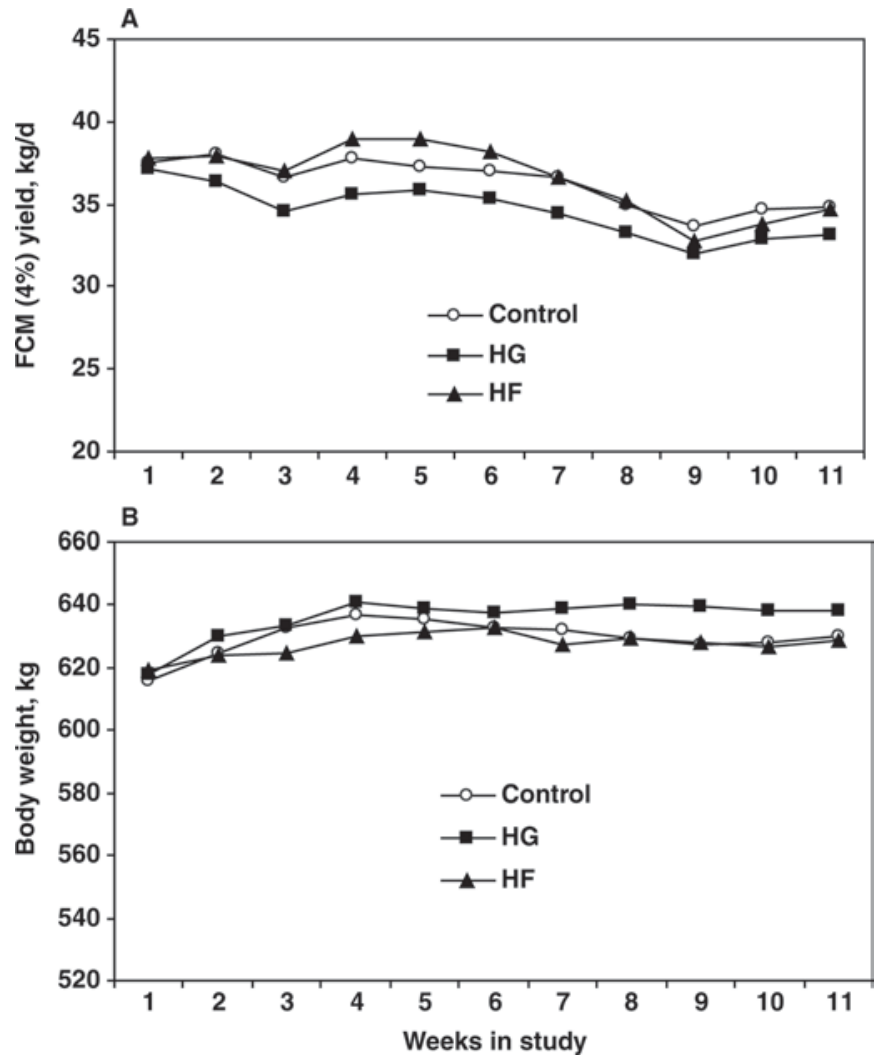

Figure 2. Temporal changes of A) FCM yield and B) BW of dairy cows fed a lactating cow ration $\left(1.75 \mathrm{Mcal}\right.$ of $\mathrm{NE}_{\mathrm{L}} / \mathrm{kg}$ of $\mathrm{DM}$; control diet; $\bigcirc)$ or supplemented with either $0.825 \mathrm{~kg} / \mathrm{d}$ per cow of ground corn grain (HG; ) or $0.300 \mathrm{~kg} / \mathrm{d}$ per cow of calcium salts of fatty acids (HF; $\mathbf{\Delta})$ during the hot season. Effects of treatment and time were significant for FCM yield and BW $(P<0.001)$. Overall SEM was 0.32 $\mathrm{kg} / \mathrm{d}$ and $3 \mathrm{~kg}$ for FCM production and BW, respectively.

in the HF group seems to indicate that the fat supplied in this diet did not impair fiber digestion.

Interestingly, the rumination time per kilogram of DM or NDF (from forage) consumed was increased by fat supplementation $(P<0.02$; Table 4 , Figure 3$)$. Generally, rumination time required for each unit of DMI is strongly associated with forage quality and is closely related to NDF consumption (Welch and Smith, 1970; Balch, 1971). However, in the present study there were no differences in forage quality between diets. Moreover, the cross-treatment correlation coefficient between DMI and rumination time per kilogram of NDF consumed was negative $(\mathrm{r}=-0.49 ; P<0.0001)$. Thus, the differences in rumination efficiency might be attributable mainly to the differences in DMI between groups, in which decreases in DMI cause increases in rumination time per unit of NDF consumed (Church, 1988). It might be that reduction in DMI decreased the emptying rate of the rumen and, consequently, enhanced rumination time per unit of DMI. However, the finding that $\mathrm{HG}$ and $\mathrm{HF}$ cows differed in rumination 


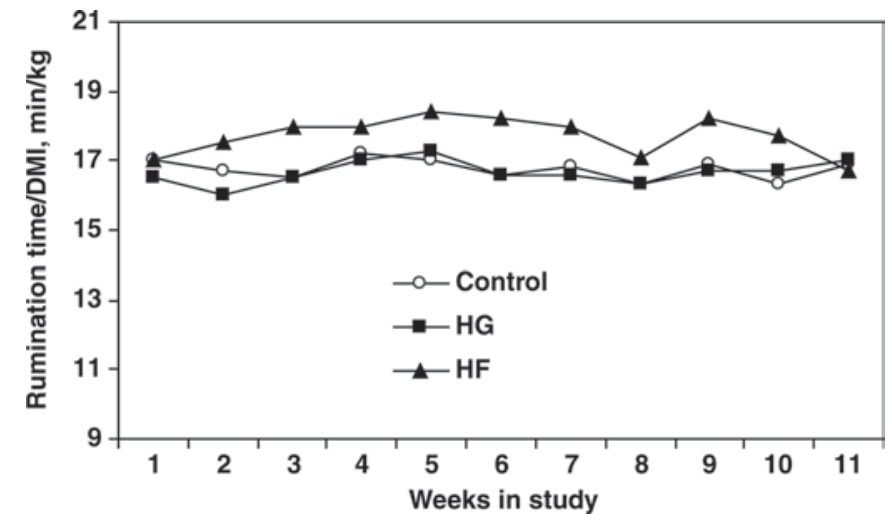

Figure 3. Average weekly rumination time per kilogram of DMI of dairy cows fed a lactating cow ration (1.75 Mcal of $\mathrm{NE}_{\mathrm{L}} / \mathrm{kg}$ of $\mathrm{DM}$; control diet; $\bigcirc$ ) or supplemented with either $0.825 \mathrm{~kg} / \mathrm{d}$ per cow of ground corn grain (HG; ) or $0.300 \mathrm{~kg} / \mathrm{d}$ per cow of calcium salts of fatty acids (HF; $\mathbf{\Delta}$ ) during the hot season. Effects of treatment and time were significant $(P<0.001)$. SEM was $0.24 \mathrm{~min} / \mathrm{kg}$ of DMI.

time per unit of DMI, although they consumed similar amounts of DM, might indicate that there also was a diet effect.

Temperature-humidity index increased in wk 7 of the study, remained high during wk 8 and 9 , and then declined until the end of the study (Figure 1A). Temporal changes in rumination time, DMI, and milk production reflected those in THI (Figures 1B, 1C, and 2A). We have analyzed the relationship between milk production, DMI, THI, DIM, and rumination time by using principal component analysis: only the first 2 components displayed eigenvalues greater than 1 and were subjected to rotation. Principal components 1 and 2 (PC1 and PC2) described 34.4 and $23.0 \%$ of the total variation, respectively, and together they accounted for $57.4 \%$ of the total variation. In interpreting the rotated factor pattern (loading $\geq 0.40$ ), milk production, DMI, and DIM were found to load on principal component 1 , whereas rumination time and THI were loaded on principal component 2. As shown also in Table 5 and Figure 4, rumination time and THI were negatively related,

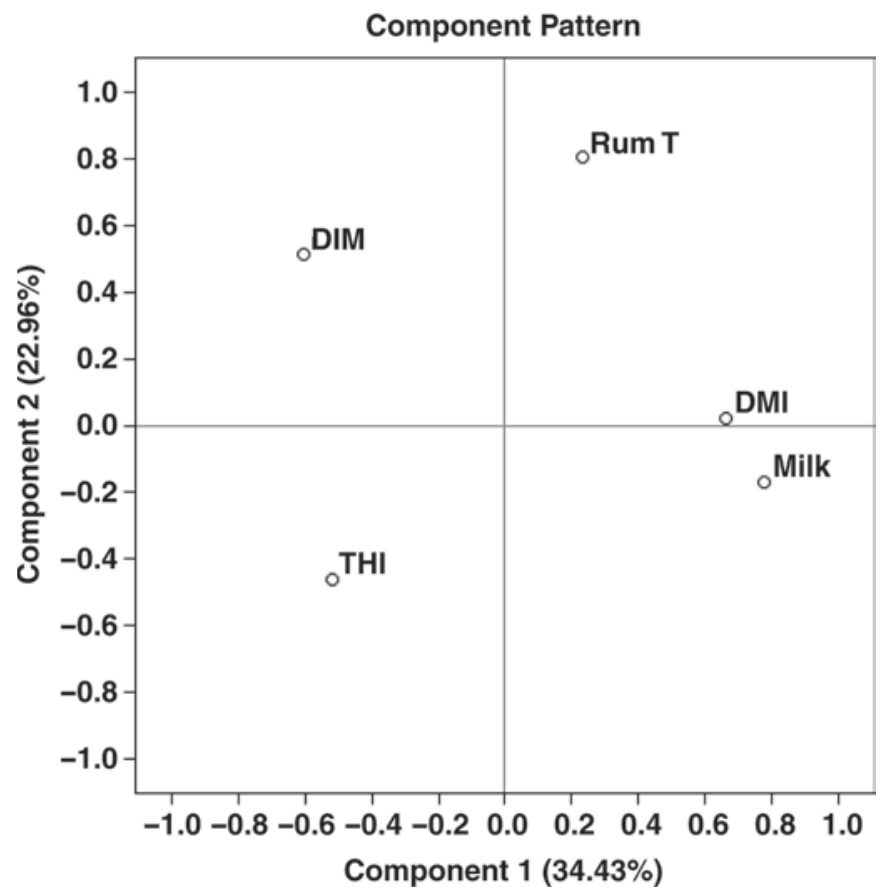

Figure 4. Plots of components pattern describing the relationship between variables derived from principal component analysis. Milk and DMI were strongly related in 1 cluster and rumination time (RumT) and temperature-humidity index (THI) were loaded in the most negative relationship.

whereas DMI and milk production were positively and strongly related. The load of rumination time in the final communality estimates was the highest (Table 5). This analysis might indicate that the primary negative effect of high THI was depression of rumination time, which subsequently led to a decline in DMI followed by reduced milk production. Depressing the rumination time might delay passage of the rumen digesta along the digestive tract, which would reduce the ruminal capacity for additional food and thereby decrease feed consumption (Church, 1988). Indeed, a delay in the passage of digesta in heat-stressed steers was reported

Table 5. Rotated factor pattern and final communality estimates from principal component analysis of variables involved in milk production during heat stress

\begin{tabular}{|c|c|c|c|c|}
\hline \multirow[b]{2}{*}{ Item } & \multicolumn{2}{|c|}{ Component $^{1}$} & \multirow{2}{*}{$\begin{array}{c}\text { Communality } \\
\text { estimates }\end{array}$} & \multirow{2}{*}{$\begin{array}{l}\text { Communality } \\
\text { estimates, \% }\end{array}$} \\
\hline & 1 & 2 & & \\
\hline Milk & 0.79 & 0.10 & 0.63 & 22.0 \\
\hline DMI & 0.81 & 0.06 & 0.44 & 15.3 \\
\hline DIM & -0.34 & 0.03 & 0.63 & 22.0 \\
\hline THI & -0.28 & -0.66 & 0.48 & 16.7 \\
\hline Rumination time & -0.07 & 0.86 & 0.70 & 24.4 \\
\hline Total & & & 2.87 & 100 \\
\hline
\end{tabular}

${ }^{1}$ Correlation coefficients between principal components 1 and 2 and tested variables.

${ }^{2}$ THI: temperature-humidity index. 
by Warren et al. (1974). It might also be postulated that chewing and rumination are impaired by panting in heat-stressed cows. Rhoads et al. (2009) found that the reduced intake under heat stress accounted for only $35 \%$ of the decrease in milk yield; therefore, $65 \%$ of the loss in milk should be attributed to other factors. The results of the present study provide a new insight in which rumination time plays a pivotal role in the negative effect of heat stress on DMI and, consequently, on milk production. However, further research is needed to examine this hypothesis.

\section{CONCLUSIONS}

Using fat supplementation to increase the dietary energy density of high-yielding mid-lactation cows under heat-stress conditions enhanced fat and FCM yields compared with those of concentrate-supplemented cows. Apparent conversion efficiency of DM and energy to milk and milk components was greater in the HF cows than in other groups but, when the energy converted to BW gain was taken into account, no differences were observed between the experimental groups' energy utilization. Moreover, MHP was similar in HF and HG cows, which did not support our premise that fat supplementation would decrease MHP more than HG would. However, it appears that MHP in the HG groups was reduced primarily through reduced energy output in milk in contrast to the HF group, in which production remained high, which also indicates different partitioning of consumed energy between fat- and concentrate-supplemented cows. Principal component analysis showed that rumination time played a pivotal role in the deleterious effect of heat stress on dairy cows' physiology and production. The overall conclusion of the present study is that increasing the dietary energy density of high-yielding mid-lactation dairy cows beyond $1.75 \mathrm{Mcal} / \mathrm{kg}$ of DM by supplementation with either concentrate or fat was not effective in enhancing production; however, fat supplementation was beneficial in increasing production efficiency.

\section{ACKNOWLEDGMENTS}

This research was partially financially supported by the Israeli Cattle Breeders' Association (Caesarea, Israel). We thank the staff of the experimental dairy farm at the Volcani Center (Bet Dagan, Israel) for their assistance with animal care.

\section{REFERENCES}

AOAC. 1990. Official Methods of Analysis. 14th ed. AOAC, Arlington, VA.
Attebery, J. T., and H. D. Johnson. 1969. Effect of environmental temperature, controlled feeding and fasting on rumen motility. J. Anim. Sci. 29:734-737.

Balch, C. C. 1971. Proposal to use time spent chewing as an index of the extent to which diets for ruminants possess the physical property of fibrousness characteristic of roughages. Br. J. Nutr. $26: 383-392$

Beauchemin, K. A., B. I. Farr, L. M. Rode, and G. B. Schaalje. 1994. Effects of alfalfa chop length and supplementary long hay on chewing and milk production of dairy cows. J. Dairy Sci. 77:1326-1339.

Beede, D. K., and R. J. Collier. 1986. Potential nutritional strategies for intensively managed cattle during thermal stress. J. Anim. Sci. 62:543-554.

Berman, A. 2008. Increasing heat stress relief produced by coupled coat wetting and forced ventilation. J. Dairy Sci. 91:4571-4578.

Berman, A., Y. Folman, M. Kaim, M. Mamen, Z. Herz, D. Wolfenson, A. Arieli, and Y. Graber. 1985. Upper critical temperatures and forced ventilation effects for high-yielding dairy cows in a subtropical climate. J. Dairy Sci. 68:1488-1495.

Bohmanova, J., I. Misztal, and J. B. Cole. 2007. Temperature-humidity indices as indicators of milk production losses due to heat stress. J. Dairy Sci. 90:1947-1956.

Chan, S. C., J. T. Huber, K. H. Chen, J. M. Simas, and Z. Wu. 1997. Effects of ruminally inert fat and evaporative cooling on dairy cows in hot environmental temperatures. J. Dairy Sci. 80:1172-1178.

Chilliard, Y. 1993. Dietary fat and adipose tissue metabolism in ruminants, pigs, and rodents: A review. J. Dairy Sci. 76:38973931.

Church, D. C. 1988. The ruminant animal-Digestive physiology and nutrition. Pages 108-116 in Ingestion of Feed and Water. J. W. Welch and A. P. Hooper, ed. Reston, Englewood Cliffs, NJ.

Collier, R. J., D. K. Beede, W. W. Thatcher, L. A. Israel, and C. J. Wilcox. 1982. Influences of environment and its modification on dairy animal health and production. J. Dairy Sci. 65:2213-2227.

Collier, R. J., J. L. Collier, R. P. Rhoads, and L. H. Baumgard. 2008. Invited review: Genes involved in the bovine heat stress response. J. Dairy Sci. 91:445-454.

Drackley, J. K., T. M. Cicela, and D. W. LaCount. 2003. Responses of primiparous and multiparous Holstein cows to additional energy from fat or concentrate during summer. J. Dairy Sci. 86:13061314.

Grum, D. E., J. K. Drackley, L. R. Hansen, and J. D. Cremin Jr. 1996. Production, digestion, and hepatic lipid metabolism of dairy cows fed increased energy from fat or concentrate. J. Dairy Sci. 79:1836-1849.

Grummer, R. R., and D. J. Carroll. 1991. Effects of dietary fat on metabolic disorders and reproductive performance of dairy cattle. J. Anim. Sci. 69:3838-3852.

Huber, J. T., G. Higginbotham, R. A. Gomez-Alarcon, R. B. Taylor, K. H. Chen, S. C. Chan, and Z. Wu. 1994. Heat stress interactions with protein, supplemental fat, and fungal cultures. J. Dairy Sci. 77:2080-2090.

IDF. 2000. IDF standard 141c:2000: Determination of milk fat, protein and lactose content-Guidance on the operation of mid-infrared instruments. International Dairy Federation, Brussels, Belgium.

Igono, M. O., G. Bjotvedt, and H. T. Sanford-Crane. 1992 Environmental profile and critical temperature effects on milk production of Holstein cows in desert climate. Int. J. Biometeorol. 36:77-87.

Kadzere, C. T., M. R. Murphy, N. Silanikove, and E. Maltz. 2002. Heat stress in lactating cows: A review. Livest. Prod. Sci. 77:59-91.

Khorasani, G. R., and J. J. Kennelly. 1998. Effect of added dietary fat on performance, rumen characteristics, and plasma metabolites of midlactation dairy cows. J. Dairy Sci. 81:2459-2468.

Knapp, D. M., and R. R. Grummer. 1991. Response of lactating dairy cows to fat supplementation during heat stress. J. Dairy Sci. $74: 2573-2579$.

Moallem, U., M. Katz, A. Arieli, and H. Lehrer. 2007. Effects of peripartum propylene glycol or fats differing in fatty acid profiles 
on feed intake, production, and plasma metabolites in dairy cows. J. Dairy Sci. 90:3846-3856.

Moody, E. G., P. J. van Soest, R. E. McDowell, and G. L. Ford. 1967. Effect of high temperature and dietary fat on performance of lactating cows. J. Dairy Sci. 50:1909-1916.

Mosley, S. A., E. E. Mosley, B. Hatch, J. I. Szasz, A. Corato, N. Zacharias, D. Howes, and M. A. McGuire. 2007. Effect of varying levels of fatty acids from palm oil on feed intake and milk production in Holstein cows. J. Dairy Sci. 90:987-993.

NRC. 2001. Nutrient Requirements of Dairy Cattle. 7th rev. ed. National Academy of Sciences, Washington, DC.

Purwanto, B. P., Y. Abo, R. Sakamoto, F. Furumoto, and S. Yamamoto. 1990. Diurnal patterns of heat production and heart rate under thermoneutral conditions in Holstein Friesian cows differing in milk production. J. Agric Sci. (Camb.) 114:139-142.

Rhoads, M. L., R. P. Rhoads, M. J. VanBaale, R. J. Collier, S. R. Sanders, W. J. Weber, B. A. Crooker, and L. H. Baumgard. 2009. Effects of heat stress and plane of nutrition on lactating Holstein cows: I. Production, metabolism, and aspects of circulating somatotropin. J. Dairy Sci. 92:1986-1997.

SAS Institute. 2002. SAS User's Guide: Statistics. Version 9.2. SAS Inst. Inc., Cary, NC.

Shwartz, G., M. L. Rhoads, M. J. VanBaale, R. P. Rhoads, and L. H. Baumgard. 2009. Effects of a supplemental yeast culture on heat stressed lactating Holstein cows. J. Dairy Sci. 92:935-942.

Skaar, T. C., R. R. Grummer, M. R. Dentine, and R. H. Stauffacher. 1989. Seasonal effects of prepartum and postpartum fat and niacin feeding on lactation performance and lipid metabolism. J. Dairy Sci. 72:2028-2038.
Sklan, D., U. Moallem, and Y. Folman. 1991. Effect of feeding calcium soaps of fatty acids on production and reproductive responses in high producing lactating cows. J. Dairy Sci. 74:510-517.

Sukhija, P. S., and D. L. Palmquist. 1990. Dissociation of calcium soaps of long-chain fatty acids in rumen fluid. J. Dairy Sci. 73:1784-1787.

van Knegsel, A. T. M., H. van den Brand, J. Dijkstra, W. M. van Straalen, M. J. W. Heetkamp, S. Tamminga, and B. Kemp. 2007. Dietary energy source in dairy cows in early lactation: Energy partitioning and milk composition. J. Dairy Sci. 90:1467-1476.

van Soest, P. J. 1963. Ruminant fat metabolism with particular reference to factors affecting low milk fat and feed efficiency. A review. J. Dairy Sci. 46:204-216.

Vazquez-Añon, M., S. J. Bertics, and R. R. Grummer. 1997. The effect of dietary energy source during mid to late lactation on liver triglyceride and lactation performance of dairy cows. J. Dairy Sci. 80:2504-2512.

Warren, W. P., F. A. Martz, K. H. Asay, E. S. Hilderbrand, C. G Payne, and J. R. Vogt. 1974. Digestibility and rate of passage by steers fed tall fescue, alfalfa and orchard grass hay in 18 and $32 \mathrm{C}$ ambient temperatures. J. Anim. Sci. 39:93-96.

Welch, J. G., and A. M. Smith. 1970. Forage quality and rumination time in cattle. J. Dairy Sci. 53:797-800.

West, J. W. 2003. Effects of heat-stress on production in dairy cattle. J. Dairy Sci. 86:2131-2144

Wu, Z., J. T. Huber, F. T. Sleiman, J. M. Simas, K. H. Chen, S. C. Chan, and C. Fontes. 1993. Effect of three supplemental fat sources on lactation and digestion in dairy cows. J. Dairy Sci. $76: 3562-3570$ 